\title{
Do Overconfident CEOs Pay More to Shareholders? Evidence from the US Market
}

\author{
Artem Anilov \\ Senior Expert \\ ORCID \\ E-mail: aeanilov@gmail.com \\ PJSC LUKOIL, Moscow, Russia
}

Journal of Corporate Finance Research, Vol. 13, No. 2, pp. 25-35 (2019)

DOI: https://doi.org/10.17323/j.jcfr.2073-0438.13.2.2019.25-35

Received 27 February 2019 | Peer-reviewed 17 March 2019 | Accepted 3 June 2019 


\section{Do Overconfident CEOs Pay More to Shareholders? Evidence from the US Market}

\section{Abstract}

This paper aims to discover evidence on the possible impact of CEO overconfidence on payout policy, and the role of corporate boards in offsetting the possible negative effects of this overconfidence. Our investigation demonstrates the effect of overconfidence on the choice of payout method, specifically regarding the repurchases-dividends mix. We also evaluate the ability of corporate governance mechanisms to reduce or even eliminate the negative effects of CEO behavior on payout decisions.

This study is conducted using a sample of 671 non-financial companies from the US for the period of 2007-2016. We apply probit regressions to study different aspects of payout decisions, and use a panel GMM estimator to check for possible endogenous effects. Using a corporate governance quality index, we test the ability of boards of directors to reduce negative effects of CEO's overconfidence on the payout decisions.

Our findings confirm the hypothesis that overconfident CEOs tend to increase the levels of payout in the form of repurchases, while the levels of cash dividends are unaffected by this type of CEO behavior. Moreover, an overconfident $\mathrm{CEO}$ is more likely to initiate repurchases if this has not been done already. The results further illustrate that overconfident CEOs not only pursue higher levels of repurchases, but also switch more often from cash dividends to repurchases. However, it is also shown, in contract to previous research in the field, that efficient boards of directors have very limited power in eliminating the negative effects of CEO overconfidence.

This paper contributes to the existing literature by analyzing the specific area of CEO overconfidence using data from the United States, and follows specific lines of inquiry which have not been deeply studied. Further possibilities to explore the implications of this research exists particularly in the consideration of its apparent contradiction of previous research. There is yet scope to determine applicable tools of reducing the negative effects of specific CEO behaviors. It is possible to identify and investigate other relevant behavioral characteristics that may influence payout decisions. Further, these characteristics may be evaluated to see if the operation of these interrelations reproduce alternative results in terms of the effect of corporate governance, both in the US and in other markets.

Keywords: payout policy, behavioral corporate finance, overconfidence, share repurchases, corporate governance, board of directors

JEL classification: G34, G35, G41 


\section{Introduction}

Recent studies have shown that CEO overconfidence might significantly affect a company's choice of payout policy [1]. For example, if a CEO is overconfident, he or she will pay fewer dividends [2]. In addition, it has been shown that overconfident CEOs tend to overinvest, so they are left with fewer funds to distribute among shareholders $[3,4]$. However, such behavior may stimulate CEOs to repurchase stocks, as they tend to treat the company's shares as undervalued $[5,6]$. Therefore, the effect on the total payout may be mixed depending on the fraction of repurchases in total payout.

Despite a significant amount of focus on CEO overconfidence $v i s-\grave{a}$-vis the relationship to payout policy, there are still some limitations in the current state of analysis on this. First, no evidence has been found as to whether or not overconfidence affects decisions about payout initiations. Second, it is not clear if overconfidence has any effect on the choice of the payout channel (e.g. payouts through repurchases versus payouts through cash dividends). Third, although it has been shown that in some cases the corporate governance mechanisms (for example, boards of directors) may be used to increase payout levels [7], there were no prior tests to provide evidence that corporate governance may eliminate or even reduce the negative impact of CEO's overconfidence on strategic decisions, including payout decisions.

To fill these informational gaps, we propose to use two specifications to measure overconfidence in this study: the level of exercisable options, and the level of exercised executive options. We also develop an index of corporate governance quality in order to assess the ability of boards of directors to reduce the negative effects of CEO overconfidence.

First, we show that overconfidence has a significant positive influence on repurchases. This means that a more overconfident CEO pays out more in the form of repurchases. Still, there is no evidence found for the effects of overconfidence on the dividends level.

Second, the level of exercisable options has a significant positive effect on the decision to initiate repurchases and on the fraction of repurchases in the total payout. This means that more overconfident CEOs are more likely to start paying out in the form of repurchases.

Third, we show that overconfident CEOs tend to switch from cash dividends to repurchases so that overall they maintain higher levels of repurchases in total payout to shareholders.

Fourth, to investigate the ability of corporate governance to counter the negative effects of CEO behavior on the payout decisions, we construct an index of corporate governance quality, which accounts for the size of the board of directors, the number of women and independent directors, CEO duality, and the frequency of relevant meetings. Unfortunately, we have not found any evidence supporting the ability of corporate governance mechanisms to eliminate or reduce the adverse effects of CEO overconfidence.
The second section of the paper presents a review of the literature on CEO overconfidence. In the third section we formulate the hypotheses based on the reviewed literature and develop our research model. The fourth section presents the discussion of our findings. The fifth section concludes our analysis and proposes questions for further research.

\section{Literature review}

The traditional theories of dividend policy (signaling theory, agency theory, catering theory) are all based on the assumption that economic agents (for instance, managers, investors, shareholders) are fully rational. However, in 1979 Kahneman and Tversky showed that people are subject to several biases (overconfidence, hindsight, anchoring and so on) which affect their decisions [8]. This idea was subsequently implemented in financial theories and academics started to take irrationality into account. Researchers added the behavioral characteristics of CEOs to the variable factors for the analysis of strategic decisions about payout, capital structure and investment policy. Among these characteristics the most widespread were risk-preferences and overconfidence. In this research, we focus on overconfidence.

The trickiest part in analyzing the behavioral patterns of CEOs and their impact in strategic decisions is quantifying these behavioral characteristics. One approach to this is to measure the option holding period $[2,9,10]$. For example, if the CEO does not exercise the executive stock option until the year of expiration, even if it is already in the money, then it can be assumed that this particular CEO hopes that stock price is going to rise further. Such behavior can be considered as a sign of overconfidence because the CEO is confident that the price will be rising continually.

The second approach to determine the level of CEO overconfidence is to search for certain keywords in interviews with CEOs and in media publications. Such words can include "overconfident", "optimistic" and their synonyms $[6,11]$. This approach can prove reliable but takes more time and effort. However, it can be affected by subjectivity of interviewers or media persons.

The third approach to approximate the level of a CEO's overconfidence is to measure the volatilities of the price and trading volume of a company's shares [12]. It is assumed that an overconfident CEO can attract shortterm investors and noise traders who are willing to accept higher risks. This can be done through optimistic statements about a company's future and about the prospects of investment projects, or by the acceptance of risky projects. Such investors may increase volatility in stock prices. Moreover, overconfident managers can trade stock on their own, increasing trading volumes and volatility. In this paper we use the first approach as it has proven to be efficient in previous studies $[9,10]$, and is easier to utilize in terms of implementation and interpretation of results. 
Using these approaches researchers have shown that overconfident managers were likely to boost investments, especially high-risk investments, and research and development expenses $[1,2,4,5]$. As a result, there was little spare cash left to distribute among shareholders and both dividends and repurchases decreased. On the contrary, some researchers have shown that despite the fact that overconfident CEOs on average pay fewer cash dividends, they tend to increase payouts in the form of repurchases $[6,13]$. This may happen because they think that a company's shares are undervalued and are going to appreciate. Given this fact, it can be assumed that the effect of overconfidence for the total payout (sum of dividends and repurchases) can be either positive or negative.

Despite the controversy about the impact that overconfidence has on the level of repurchases, researchers agree that CEO overconfidence does not always help shareholders with building up their wealth. How could shareholders then be protected against the negative effects of CEO's overconfidence? One approach to this problem is setting the level of dividend protection according to the level of the CEO's compensation [14]. This means that the CEO's compensation is developed in such a way that prevents the decrease in value of the CEO's holdings in case of a dividend payout.

A CEO's compensation is set by the board of directors. This, as an agent of corporate governance, is an entity that represents the shareholders' interests in the company and aims to minimize agency conflicts. It has been empirically proven that the more efficient the corporate governance is, the more the company pays out $[7,15,16]$ and therefore the higher profitability a company achieves $[17,18]$. The efficiency of corporate governance may be measured by the size of the board, by the number of independent directors, the length of membership, the representation of government on the board, and other characteristics taken together as an index or separately. Gender diversity also may be a measure of efficiency as it has been shown that female directors may decrease the level of CEO overconfidence [19]. However, there is also evidence that in some markets an increase in the number of independent directors may lead to an increase in R\&D investments [20], which are associated with high risk and overconfidence.

Given the findings of previous research, it may be asserted that an overconfident CEO's behavior may affect corporate decisions, and corporate governance tools are possibly able to reduce the negative effects. However, there are some limitations in the current analysis. First, there are no clear data regarding payouts in the form of dividends. Second, there are no clear results as to the impact of a CEO's overconfidence on the decision to start paying out and on the fraction of repurchases in the total payout. Third, there are still some measures of overconfidence that were not studied in the context of payout policy. Fourth, there is very limited direct evidence on the ability of corporate governance to eliminate the negative effects of CEO's overconfidence.

To overcome these limitations, and to further boost the research in behavioral corporate finance, we address these issues and provide empirical evidence based on an evaluation of a sample of US companies.

\section{Hypotheses development and model}

Having analyzed previous research on CEO overconfidence, we may conclude that the behavior of a CEO can significantly influence his or her corporate decisions. If this is the case, the shareholders' wealth may be damaged. It is assumed that corporate governance may be used to overcome the negative effects of a CEO's behavior.

In this paper the following hypotheses are tested:

1) The higher the level of overconfidence of the $\mathrm{CEO}$, the higher the level of payout in the form of repurchases. This proposition is based on the assumption that an overconfident CEO treats the company's shares as undervalued and tends to repurchase them at what is thought to be a low price [5];

2) The higher the level of overconfidence of the $\mathrm{CEO}$, the higher the probability of initiating the repurchase [5];

3) The higher the level of overconfidence of the CEO, more funds are distributed through repurchases than through dividends [5];

4) High-quality corporate governance has an ability to reduce the negative effects of a CEO's overconfidence.

To test these hypotheses we applied several techniques. To address the possible issues of endogeneity we applied general method of moments (hypotheses 1 and 3 ). Additionally, to test Hypothesis 2 we used a panel probit regression, as the dependent variable is a binary one.

We develop the following models to test the hypotheses:

$$
\begin{aligned}
& \text { Payout }_{\mathrm{i}, \mathrm{t}}=\alpha+\beta_{1} \cdot \text { Payout }_{\mathrm{i}, \mathrm{t}-1}+\beta_{2} \cdot \text { Age }_{\mathrm{i}, \mathrm{t}}+ \\
& +\beta_{3} \cdot \text { Overconf }_{\mathrm{i}, \mathrm{t}}+\sum_{\mathrm{k}=4}^{11} \beta_{\mathrm{k}} \cdot \text { Control }_{\mathrm{i}, \mathrm{t}, \mathrm{k}}+\theta_{\mathrm{i}}+\delta_{\mathrm{t}}+\varepsilon_{\mathrm{i}, \mathrm{t}} \\
& \operatorname{pr}\left(\mathrm{DTP}_{\mathrm{i}, \mathrm{t}}=1\right)=\varphi\left\{\mu+\gamma_{1} \cdot \mathrm{DTP}_{\mathrm{i}, \mathrm{t}-1}+\gamma_{3} \cdot \text { Age }_{\mathrm{i}, \mathrm{t}}+\right. \\
& \left.+\gamma_{3} \bullet \text { Overconf }_{\mathrm{i}, \mathrm{t}}+\sum_{\mathrm{k}=4}^{11} \gamma_{\mathrm{k}} \cdot \text { Control }_{\mathrm{i}, \mathrm{t}, \mathrm{k}}+\theta_{\mathrm{i}}+\delta_{\mathrm{t}}\right\}
\end{aligned}
$$

where Payout $_{\mathrm{i}, \mathrm{t}}$ - is the one of the three "Payout" variables; $\mathrm{DTP}_{\mathrm{i}, \mathrm{t}}$ - is one of the two "Decision to pay" variables; Overconf $_{\mathrm{i}, \mathrm{t}}$ - is one of the two "Overconfidence" variables; Age - is the age of the CEO; Contlol $_{\mathrm{i}, \mathrm{t}}$ - is the set of control variables; $\varphi\{\mathrm{x}\}$ is the standard normal cumulative distribution function; $\alpha, \beta_{\mathrm{k}}, \mu, \gamma_{\mathrm{k}}$ are coefficients for regressions; $e_{\mathrm{i}, \mathrm{t}}$, are normally distributed error terms; $\theta_{\mathrm{i}}$ are individual effects; $\delta_{\mathrm{t}}$ are the year's effects; i is the company index; and $\mathrm{t}$ is the year index.

Two specifications of CEO overconfidence are used. The first one is the ratio of value of exercisable executive options to the value of all executive options that the CEO owns. 
Table 1. The variables

\begin{tabular}{|c|c|c|}
\hline Variable type & Variable name & Measure \\
\hline \multirow{3}{*}{ Payout } & Dividend ratio & $\begin{array}{l}\text { The ratio of cash dividends on common and preferred stocks } \\
\text { to total assets }\end{array}$ \\
\hline & Repurchase ratio & The ratio of repurchases to total assets \\
\hline & Fraction of repurchases & The ratio of repurchases to total payout \\
\hline \multirow{2}{*}{ Decision to pay } & Decision to pay dividends & 1 if cash dividends take place, 0 otherwise \\
\hline & Decision to repurchase & 1 if repurchases take place, 0 otherwise \\
\hline \multirow{2}{*}{ Overconfidence } & CEO exercisable options & $\begin{array}{l}\text { The ratio of value of exercisable executive options to the value } \\
\text { of all the CEO's executive options }\end{array}$ \\
\hline & CEO exercised options & $\begin{array}{l}\text { The ratio of exercised executive options to the value of exer- } \\
\text { cisable executive options at the beginning of the year }\end{array}$ \\
\hline Age & CEO Age & Age of the CEO \\
\hline \multirow{8}{*}{ Control variables } & Cash & The ratio of cash holdings to total assets \\
\hline & Tobin's Q & The ratio of market value of equity to book value of equity \\
\hline & Debt to equity & The ratio of book value of debt to equity \\
\hline & Capital expenditures & The ratio of capital expenditures to total assets \\
\hline & Research and development & The ratio of $R \& D$ expenses to total assets \\
\hline & Long-term debt & Long-term debt to total debt \\
\hline & Return on assets & The ratio of net income to total assets \\
\hline & Size & Natural logarithm of total assets \\
\hline
\end{tabular}

Table 2. Expected signs of the impact of overconfidence on the payout ratios

\begin{tabular}{|c|c|c|}
\hline Overconfidence & $\begin{array}{l}\text { Expected impact } \\
\text { on the dividend ratios }\end{array}$ & $\begin{array}{c}\text { Expected impact } \\
\text { on the repurchase ratios }\end{array}$ \\
\hline CEO exercisable options & - & + \\
\hline CEO exercised options & + & - \\
\hline
\end{tabular}

It is assumed that if this ratio is high then the CEO postpones the exercising of options. Such a CEO is treated as overconfident because he or she believes that the company's shares will keep increasing in value and the CEO will be able profit more. The second measure is the ratio of exercised executive options to the value of exercisable executive options at the beginning of the year. It is assumed that if this ratio is low then the CEO is not willing to exercise his or her options. Again, such a CEO is treated as overconfident for the same reason.

The CEO's age also can be a measure of CEO behavior because it is assumed that older people are more cautious and less willing to take certain risks.
The definitions of the variables for Models (1) and (2) are presented in Table 1.

The predictions about the impact of independent variables on the payout are summarized in Table 2.

As stated earlier, overconfident CEOs may prefer repurchases to dividends. That is why we believe that the impact of overconfidence on repurchases and dividends will be opposite.

Taking into account the strategic role of the board of directors in protecting shareholders' interests, we study its power to reduce the negative effects of CEO overconfidence. 
We therefore develop the corporate governance quality index (CGQI) based on the following board characteristics which were studied in previous research [21]:

1) The presence of women $[19,22]$.

2) The percentage of independent directors [23].

3) CEO duality [24].

4) The frequency of board meetings [25].

5) The size of the board [26].

We apply a value of 1 or 0 to each characteristic and present an index value from 0 (poor corporate governance quality) to 5 (excellent corporate governance quality).

We create a dummy variable $\mathrm{D}_{\mathrm{i}, \mathrm{f}}$ for companies that have a value of CGQI from 4 to 5 (efficient corporate governance), which is strictly above the mean value for the sample (see Table 3 below).

To test Hypothesis 4, we add a dummy variable for high-quality corporate governance. Thus, we extend Models (1) and (2) and assess Models (3) and (4):

$$
\begin{aligned}
& \text { Payout }_{\mathrm{i}, \mathrm{t}}=\alpha+\beta_{1} \cdot \text { Payout }_{\mathrm{i}, \mathrm{t}-1}+\beta_{2} \cdot \mathrm{Age}_{\mathrm{i}, \mathrm{t}}+\beta_{12} \bullet \\
& \text {-Age } \mathrm{i}_{\mathrm{i}, \mathrm{t}} \cdot \mathrm{D}_{\mathrm{i}, \mathrm{t}}+\beta_{3} \cdot \text { Overconf }_{\mathrm{i}, \mathrm{t}}+\beta_{13} \cdot \text { Overconf }_{\mathrm{i}, \mathrm{t}} \cdot \\
& \cdot \mathrm{D}_{\mathrm{i}, \mathrm{t}}+\sum_{\mathrm{k}=4}^{11} \beta_{\mathrm{k}} \cdot \text { Control }_{\mathrm{i}, \mathrm{t}, \mathrm{k}}+\theta_{\mathrm{i}}+\delta_{\mathrm{t}}+\varepsilon_{\mathrm{i}, \mathrm{t}} \\
& \operatorname{pr}\left(\mathrm{DTP}_{\mathrm{i}, \mathrm{t}}=1\right)=\varphi\left\{\mu+\gamma_{1} \cdot \mathrm{DTP}_{\mathrm{i}, \mathrm{t}-1}+\gamma_{2} \bullet \mathrm{Age}_{\mathrm{i}, \mathrm{t}}+\right. \\
& +\gamma_{12} \cdot \operatorname{Age}_{\mathrm{i}, \mathrm{t}} \cdot \mathrm{D}_{\mathrm{i}, \mathrm{t}}+\gamma_{3} \bullet \text { Overconf }_{\mathrm{i}, \mathrm{t}}+\gamma_{13} \bullet \\
& \left.\cdot \text { Overconf }_{\mathrm{i}, \mathrm{t}} \cdot \mathrm{D}_{\mathrm{i}, \mathrm{t}}+\sum_{\mathrm{k}=4}^{11} \gamma_{\mathrm{k}} \cdot \text { Control }_{\mathrm{i}, \mathrm{t}, \mathrm{k}}+\theta_{\mathrm{i}}+\delta_{\mathrm{t}}\right\} \text {, }
\end{aligned}
$$

where $\mathrm{D}_{\mathrm{i}, \mathrm{t}}$ is the dummy variable for high-quality corporate governance; $\beta_{12}, \beta_{13}$ and $\gamma_{12}, \gamma_{13}$ are the coefficients for companies with high-quality governance.

First of all, we check whether the coefficients $\beta_{2}, \beta_{3}, \gamma_{2}$, $\gamma_{3}$ and $\beta_{12}, \beta_{13}, \gamma_{12}, \gamma_{13}$ are significant. If they are not, then the corporate governance does not have an ability to eliminate the negative effects of the CEO's overconfidence. If they are significant, we move to the next step.

If corporate governance eliminates completely the impact of the CEO's overconfidence on their decisions, then the following equations should hold:

$$
\begin{aligned}
& \beta_{2}=-\beta_{12} \text { and } \gamma_{2}=-\gamma_{12} ; \\
& \beta_{3}=-\beta_{13} \text { and } \gamma_{3}=-\gamma_{13} .
\end{aligned}
$$

We use Wald statistics to check whether these equations are true.
In addition to these variables and based on previous research (see Table 2), we add a set of control variables (Cash holdings, Tobin's Q, Debt-to-Equity ratio, Longterm Debt ratio, Capital and R\&D expenditures, ROA and Size) representing the financial position of the company. To capture possible effects, we also include company dummies and year dummies.

To sum up, unlike previous studies, we include in our analysis the relationship between overconfidence and the repurchases-dividends mix, the impact of overconfidence on the decision to initiate payouts in different forms, and the power of corporate governance.

The research is conducted on a sample of 671 non-financial and non-utilities companies from the USA for the period of 2007-2016. To build the sample, we take companies from S\&P 1500 Index. The sample is further restricted to companies that had positive payouts at least once during the period. After adjusting for the missing data and outliers, we come up with a final sample of 671 companies. The data was obtained from the S\&P Capital IQ and Bloomberg databases.

To assess Models (1) and (3), we use the dynamic panel data method, namely the Arellano-Bond estimator. We do so to address lagged variables. We also run Arellano-Bond tests for autocorrelation, and the Hansen test for instruments validity. To address the initial conditions problem, for Models (2) and (4) a panel probit model regression has been applied [27]. For all models the robust standard errors at firm level and standardized variables have been used.

The next section discusses the obtained results.

\section{Results}

We start with the discussion of descriptive statistics that are presented for the non-standardized variables.

Table 3 reports that CEOs in the sample have different characteristics: some of them exercised all available options and some of them did not exercise any of them. The total payout variable mostly consists of repurchases in US companies. As previously mentioned, this fact should be considered pertinent when interpreting results and conclusions.

Table 4 summarizes the results of Models (1) and (2) testing. The results show coefficients for the standardized variables for all Models.

Table 3. The descriptive statistics

\begin{tabular}{lcccc} 
Variable & Mean & Standard Deviation & Min & Max \\
CGQI & 3.642 & .809 & 1.000 & 5.000 \\
CEO exercisable options & .479 & .413 & .000 & 1.000 \\
\hdashline CEO exercised options & .258 & .359 & .000
\end{tabular}




\begin{tabular}{|c|c|c|c|c|}
\hline Variable & Mean & Standard Deviation & Min & $\operatorname{Max}$ \\
\hline CEO age & 57.729 & 6.187 & 36.000 & 86.000 \\
\hline Dividend ratio & .014 & .024 & .000 & .316 \\
\hline Repurchase ratio & .035 & .062 & .000 & .880 \\
\hline Fraction of repurchases & .494 & .420 & .000 & 1.000 \\
\hline Cash & .118 & .112 & .000 & .880 \\
\hline Tobin’s Q & 1.927 & 1.800 & .000 & 53.170 \\
\hline Debt to equity & .353 & .439 & .000 & 4.036 \\
\hline Capital expenditures & .048 & .051 & .000 & .460 \\
\hline $\mathrm{R} \& \mathrm{D}$ expenses & .022 & .043 & .000 & .580 \\
\hline Long-term debt & .694 & .386 & .000 & 1.000 \\
\hline Decision to pay dividends & .595 & .491 & .000 & 1.000 \\
\hline Decision to repurchase & .692 & .462 & .000 & 1.000 \\
\hline Return on assets & .054 & .089 & -1.260 & .560 \\
\hline Size & 7.849 & 1.619 & 3.892 & 13.590 \\
\hline
\end{tabular}

Table 4. Results of testing Hypotheses 1, 2 and $3^{1}$

\begin{tabular}{|c|c|c|c|c|c|}
\hline & \multicolumn{5}{|c|}{ Dependent variables } \\
\hline & $\begin{array}{l}\text { Repurchase } \\
\text { ratio }\end{array}$ & $\begin{array}{l}\text { Dividend } \\
\text { ratio }\end{array}$ & $\begin{array}{l}\text { Repurchase } \\
\text { fraction }\end{array}$ & $\begin{array}{l}\text { Decision to } \\
\text { repurchase }\end{array}$ & $\begin{array}{l}\text { Decision to pay } \\
\text { dividends }\end{array}$ \\
\hline CEO exercisable options & $\begin{array}{l}0.164^{*} \\
(1.95)\end{array}$ & $\begin{array}{l}-0.002 \\
(-0.05)\end{array}$ & $\begin{array}{l}0.132^{* *} \\
(2.25)\end{array}$ & $\begin{array}{c}0.069^{* * *} \\
(3.40)\end{array}$ & $\begin{array}{l}0.075^{* *} \\
(2.11)\end{array}$ \\
\hline $\begin{array}{l}\text { CEO exercised } \\
\text { options }\end{array}$ & $\begin{array}{l}0.297^{\star} \\
(1.68)\end{array}$ & $\begin{array}{l}-0.030 \\
(-0.37)\end{array}$ & $\begin{array}{l}0.209^{*} \\
(1.73)\end{array}$ & $\begin{array}{l}0.034^{*} \\
(1.74)\end{array}$ & $\begin{array}{l}0.025 \\
(0.65)\end{array}$ \\
\hline CEO age & $\begin{array}{l}0.542 \\
(1.30)\end{array}$ & $\begin{array}{l}0.160 \\
(0.97)\end{array}$ & $\begin{array}{l}0.181 \\
(1.09)\end{array}$ & $\begin{array}{l}0.014 \\
(0.54)\end{array}$ & $\begin{array}{l}0.033 \\
(0.89)\end{array}$ \\
\hline $\begin{array}{l}\text { Dependent } \\
\text { variable (t-1) }\end{array}$ & $\begin{array}{c}0.230^{* * *} \\
(4.82)\end{array}$ & $\begin{array}{c}0.481^{\star * *} \\
(3.45)\end{array}$ & $\begin{array}{c}0.369^{* * *} \\
(12.74)\end{array}$ & $\begin{array}{l}1.323^{\star * *} \\
(28.62)\end{array}$ & $\begin{array}{l}3.653^{* * *} \\
(44.82)\end{array}$ \\
\hline Cash & $\begin{array}{l}0.312 \\
(1.59)\end{array}$ & $\begin{array}{l}-0.114^{*} \\
(-1.75)\end{array}$ & $\begin{array}{l}0.095 \\
(0.83)\end{array}$ & $\begin{array}{l}0.018 \\
(0.69)\end{array}$ & $\begin{array}{l}0.001 \\
(0.02)\end{array}$ \\
\hline Tobin’s Q & $\begin{array}{l}0.209 \\
(0.59)\end{array}$ & $\begin{array}{l}0.301^{* *} \\
(2.47)\end{array}$ & $\begin{array}{l}-0.120 \\
(-0.84)\end{array}$ & $\begin{array}{l}-0.001 \\
(-0.06)\end{array}$ & $\begin{array}{l}0.024 \\
(0.76)\end{array}$ \\
\hline
\end{tabular}

\footnotetext{
${ }^{1}$ This table presents results from the Arellano-Bond two-step GMM estimator and panel probit regressions for the complete sample. All regressions include intercept and dummies for companies. z-Statistics for Arellano-Bond and for probit are reported in parentheses below each coefficient estimate. P-values for Wald stat., Hansen test and the Arellano-Bond tests are reported in the parentheses below each statistics. ${ }^{*},{ }^{* *}$, and ${ }^{* * *}$ denote statistical significance at the $10 \%, 5 \%$ and $1 \%$ levels, respectively.
} 


\begin{tabular}{|c|c|c|c|c|c|}
\hline Debt to equity & $\begin{array}{l}0.098 \\
(0.24)\end{array}$ & $\begin{array}{l}-0.087 \\
(-0.38)\end{array}$ & $\begin{array}{l}-0.162 \\
(-0.65)\end{array}$ & $\begin{array}{l}-0.032 \\
(-1.18)\end{array}$ & $\begin{array}{c}-0.068^{*} \\
(-1.84)\end{array}$ \\
\hline Capital expenditures & $\begin{array}{l}-0.173^{*} \\
(-1.86)\end{array}$ & $\begin{array}{l}0.010 \\
(0.25)\end{array}$ & $\begin{array}{l}-0.091 \\
(-1.08)\end{array}$ & $\begin{array}{l}-0.014 \\
(-0.52)\end{array}$ & $\begin{array}{l}0.006 \\
(0.12)\end{array}$ \\
\hline $\mathrm{R} \& \mathrm{D}$ expenses & $\begin{array}{l}0.288^{\star} \\
(1.95)\end{array}$ & $\begin{array}{l}0.009 \\
(0.15)\end{array}$ & $\begin{array}{l}0.086 \\
(1.04)\end{array}$ & $\begin{array}{c}0.060^{* *} \\
(2.31)\end{array}$ & $\begin{array}{l}-0.045 \\
(-1.16)\end{array}$ \\
\hline Long-term debt & $\begin{array}{c}0.724^{\star *} \\
(2.15)\end{array}$ & $\begin{array}{l}0.030 \\
(0.18)\end{array}$ & $\begin{array}{l}0.117 \\
(0.59)\end{array}$ & $\begin{array}{c}0.041^{*} \\
(1.63)\end{array}$ & $\begin{array}{l}0.048 \\
(1.08)\end{array}$ \\
\hline ROA & $\begin{array}{l}0.066^{*} \\
(1.66)\end{array}$ & $\begin{array}{l}-0.013 \\
(-0.57)\end{array}$ & $\begin{array}{c}0.089^{* * *} \\
(2.96)\end{array}$ & $\begin{array}{c}0.156^{\star * *} \\
(6.57)\end{array}$ & $\begin{array}{c}0.166^{\star * *} \\
(4.00)\end{array}$ \\
\hline Size & $\begin{array}{l}-0.718 \\
(-1.33)\end{array}$ & $\begin{array}{l}-0.183 \\
(-0.67)\end{array}$ & $\begin{array}{l}-0.245 \\
(-1.01)\end{array}$ & $\begin{array}{c}0.123^{* * *} \\
(4.26)\end{array}$ & $\begin{array}{c}0.179^{\star * *} \\
(3.75)\end{array}$ \\
\hline Year 2009 & $\begin{array}{c}-0.368^{\star * *} \\
(-5.37)\end{array}$ & $\begin{array}{c}-0.050^{\star *} \\
(-2.49)\end{array}$ & $\begin{array}{c}-0.341^{\star * *} \\
(-6.33)\end{array}$ & $\begin{array}{l}-0.637^{\star * *} \\
(-10.63)\end{array}$ & $\begin{array}{l}-0.230^{\star *} \\
(-1.99)\end{array}$ \\
\hline Year 2012 & $\begin{array}{c}-0.130^{* * *} \\
(-3.49)\end{array}$ & $\begin{array}{l}0.024 \\
(1.60)\end{array}$ & $\begin{array}{c}-0.088^{* *} \\
(-2.43)\end{array}$ & $\begin{array}{l}-0.064 \\
(-1.21)\end{array}$ & $\begin{array}{c}0.221^{\star \star} \\
(2.13)\end{array}$ \\
\hline Intercept & Yes & Yes & Yes & Yes & Yes \\
\hline Individual effects & Yes & Yes & Yes & Yes & Yes \\
\hline Num. of observations & 6039 & 6039 & 6039 & 6039 & 6039 \\
\hline Method & $\begin{array}{l}\text { Arellano-Bond } \\
\text { GMM }\end{array}$ & $\begin{array}{l}\text { Arellano-Bond } \\
\text { GMM }\end{array}$ & $\begin{array}{l}\text { Arellano-Bond } \\
\text { GMM }\end{array}$ & $\begin{array}{l}\text { Panel Probit } \\
\text { regression }\end{array}$ & $\begin{array}{l}\text { Panel Probit } \\
\text { regression }\end{array}$ \\
\hline Wald stat (chi_sq) & $\begin{array}{l}140.88 \\
(0.00)\end{array}$ & $\begin{array}{c}166.89 \\
(0.00)\end{array}$ & $\begin{array}{c}353.84 \\
(0.00)\end{array}$ & $\begin{array}{c}1130.74 \\
(0.00)\end{array}$ & $\begin{array}{c}2776.70 \\
(0.00)\end{array}$ \\
\hline Hansen test & $\begin{array}{l}44.74 \\
(0.48)\end{array}$ & $\begin{array}{l}53.35 \\
(0.18)\end{array}$ & $\begin{array}{l}46.47 \\
(0.41)\end{array}$ & - & - \\
\hline $\mathrm{AB}$ test (AR 1$)$ & $\begin{array}{l}-5.49 \\
(0.00)\end{array}$ & $\begin{array}{l}-2.94 \\
(0.00)\end{array}$ & $\begin{array}{l}-14.99 \\
(0.00)\end{array}$ & - & - \\
\hline $\mathrm{AB}$ test (AR 2) & $\begin{array}{l}-0.62 \\
(0.53)\end{array}$ & $\begin{array}{c}1.06 \\
(0.29)\end{array}$ & $\begin{array}{l}-0.12 \\
(0.90)\end{array}$ & - & - \\
\hline
\end{tabular}

In line with the predictions from Table 2, the level of exercisable options has a significant positive effect on the level of repurchases. This result is also robust for all specifications of payout policy except at the level of dividends analysis. This means that more overconfident CEOs tend to repurchase more. It proves our suggestion that overconfident CEOs consider company's stocks as undervalued. However, it cannot be said that it has any significant influence on the level of cash dividends. We can conclude that the level of dividends is determined by the financial situation in a company rather than by the CEO's overconfidence.
Overconfident CEOs also prefer repurchases to dividends as the exercisable options variable has a positive impact on the fraction of repurchases. It means that overconfident CEOs not only pursue higher levels of repurchases, but also switch more to repurchases from cash dividends. Exercised options have limited influence on the payout variables, though the CEOs that exercise more options tend to set higher levels of repurchases, and also prefer repurchases as opposed to dividends. These CEOs may still pursue the goal of increasing stock price and signal to the market that the stocks are undervalued and they believe in future stock price increases. 
We can also see that the CEO's age has no influence on the payout decisions.

The same is true for initiations of repurchases: the higher the level of exercisable options, the higher the probability of repurchase initiations. It means that overconfident CEOs are more likely to initiate repurchases than dividend payouts. Marginal effects can be checked in Table 5. It can be seen that overconfident CEOs increase the probability of initiating repurchases by $2.2 \%$, and dividends by $2.6 \%$.

The results in Tables 4 and 5 show that overconfidence of the CEO may significantly affect his or her decisions about the payout policy, namely the decisions about initiation, level, and fraction of repurchases. We also show that return on assets has a positive impact on these decisions, while the crisis year of 2009 sees some negative impact, which is expected.
To verify Hypothesis 4 we run Models (3) and (4) and use Wald statistics to check the equality of behavioral coefficients. To obtain reliable results, both coefficients (with and without dummy $\mathrm{D}_{\mathrm{i}, \mathrm{f}}$ ) should be significant. The tests results are summarized in Table 6.

Coefficients of interest in Models (3) and (4) are not significant and we have not found any support for Hypothesis 4 . This indicates that efficient corporate governance cannot eliminate or reduce the negative effects of the CEO's overconfidence. Further research is needed to prove corporate governance efficiency in terms of its ability to reduce the negative effects of CEO behavior. The predictions from previous sections should be tested, along with other measures of corporate governance efficiency, for instance, term length of membership, connections to government, personal characteristics of the board members, etc.

Table 5. Marginal effects for Model (2) at average ${ }^{2}$

Dependent variables

\begin{tabular}{|c|c|c|}
\hline CEO age & $\begin{array}{l}0.004 \\
(0.54)\end{array}$ & $\begin{array}{l}0.011 \\
(0.89)\end{array}$ \\
\hline CEO exercisable options & $\begin{array}{c}0.022^{* * *} \\
(3.39)\end{array}$ & $\begin{array}{c}0.026^{* *} \\
(2.10)\end{array}$ \\
\hline CEO exercised options & $\begin{array}{c}0.011^{\star} \\
(1.74)\end{array}$ & $\begin{array}{l}0.008 \\
(0.65)\end{array}$ \\
\hline
\end{tabular}

Table 6. Results of testing Hypothesis $4^{3}$

\begin{tabular}{|c|c|c|c|c|c|}
\hline & & \multicolumn{4}{|c|}{ Dependent variables } \\
\hline & $\begin{array}{l}\text { Repurchase } \\
\text { ratio }\end{array}$ & $\begin{array}{l}\text { Dividend } \\
\text { ratio }\end{array}$ & $\begin{array}{l}\text { Repurchase } \\
\text { fraction }\end{array}$ & $\begin{array}{l}\text { Decision } \\
\text { to repurchase }\end{array}$ & $\begin{array}{l}\text { Decision to pay } \\
\text { dividends }\end{array}$ \\
\hline \multirow{2}{*}{$\begin{array}{l}\text { CEO exercisable } \\
\text { options }\end{array}$} & $3.71^{\star}$ & 1.38 & 1.34 & $4.89^{\star \star}$ & 1.10 \\
\hline & $(0.05)$ & $(0.24)$ & $(0.25)$ & $(0.03)$ & $(0.29)$ \\
\hline \multirow{2}{*}{ CEO exercised options } & $3.34^{\star}$ & 0.64 & $3.97^{\star}$ & 0.45 & 0.05 \\
\hline & $(0.07)$ & $(0.43)$ & $(0.05)$ & $(0.50)$ & $(0.83)$ \\
\hline \multirow{2}{*}{ CEO age } & 0.12 & 0.61 & 0.080 & 1.56 & 0.15 \\
\hline & $(0.73)$ & $(0.44)$ & $(0.37)$ & $(0.21)$ & $(0.70)$ \\
\hline
\end{tabular}

\footnotetext{
${ }^{2}$ This table presents at average marginal effects for the probit estimations. z-Statistics are reported in parentheses below each effect estimate. ${ }^{\star},{ }^{\star *}$, and ${ }^{* * *}$ denote statistical significance at the $10 \%, 5 \%$ and $1 \%$ levels, respectively.

${ }^{3}$ This table presents chi 2 statistics for the tests of H0. P-Values are reported in the parentheses. ${ }^{*},{ }^{* *},{ }^{* *}$ represent that H0 can be rejected at the $10 \%$, $5 \%, 1 \%$ levels respectively.
} 


\section{Conclusion}

This paper is aimed at establishing a deeper understanding of the influence of CEO overconfidence on three payout decisions: the decision to initiate payout to shareholders; the decision about the level of payout; and the decision about repurchases-dividends mix. We also aim to find support for the suggestion that corporate governance has the power to reduce or even eliminate the negative effects of a CEO's overconfidence.

Our study proves that the overconfidence of a CEO may significantly affect decisions about the choice of corporate payout policy. As in $[5,6]$, we found that more overconfident CEOs tend to repurchase more stocks. In addition, it has been proven that such CEOs are more likely to initiate repurchases and generally prefer repurchases to dividends. It proves the hypothesis that overconfident CEOs tend to believe in stocks' undervaluation by market participants.

Contrary to previous research [22], however, we found no support for the hypothesis that efficient corporate governance may eliminate or reduce negative effects of a CEO's behavior - overconfidence in this case.

It has to be pointed out that these results are sensitive to the way in which overconfidence is measured: one of the specifications (the level of exercised options) does not significantly influence payout decisions. It means that more information is needed about the most appropriate measures of CEO overconfidence.

There are still some blind spots in the investigation of the impact of CEO behavior on payout decisions. Further research is needed to determine other tools of reducing the negative effects of CEO behavior. This will involve finding other behavioral characteristics that may influence payout decisions, checking whether behavioral characteristics of other top-managers (CFO or COO) can influence these decisions, and checking the operation of these interrelations in other markets.

\section{References}

1. Hirshleifer D., Low A., Teoh S.H. Are overconfident CEOs better innovators? The Journal of Finance. 2012;67(4):1457-1498. DOI: 10.1111/j.15406261.2012.01753.x

2. Deshmukh S., Goel A.M., Howe K.M. CEO overconfidence and dividend policy. Journal of Financial Intermediation. 2013;22(3):440-463. DOI: 10.1016/j.jfi.2013.02.003

3. Choi P.M.S., Chung C.Y., Liu C. Self-attribution of overconfident CEOs and asymmetric investment cash flow sensitivity. The North American Journal of Economics and Finance. 2018;46:1-14. DOI: 10.1016/j. najef.2017.10.008

4. He Y., Chen C., Hu Y. Managerial overconfidence, internal financing and investment efficiency:
Evidence from China. Research in International Business and Finance. 2019;47:501-510. DOI: 10.1016/j.ribaf.2018.09.010

5. Fenn G.W., Liang N. Corporate payout policy and managerial stock incentives. Journal of Financial Economics. 2001;60(1):45-72. DOI: 10.1016/S0304405X(01)00039-3

6. Andreou P.C., Cooper I., de Olalla Lopez I.G., Louca C. Managerial overconfidence and the buyback anomaly. Journal of Empirical Finance. 2018;49:142156. DOI: 10.1016/j.jempfin.2018.09.005

7. Bhabra G., Luu K.H. Growth, governance and corporate payout policy. Accounting \& Finance. 2015;55(3):659-681. DOI: 10.1111/acfi.12070

8. Kahneman D., Tversky A. Prospect theory: An analysis of decision under risk. Econometrica. 1979;47(2):263-291. URL: https://www.its.caltech. edu/ camerer/Ec101/ProspectTheory.pdf

9. Malmendier U., Tate G. CEO overconfidence and corporate investment. The Journal of Finance. 2005;60(6):2661-2700. DOI: 10.1111/j.15406261.2005.00813.x

10. De Cesari A., Ozkan N. Executive incentives and payout policy: Empirical evidence from Europe. Journal of Banking \& Finance. 2015;55:70-91. DOI: 10.1016/j.jbankfin.2014.12.011

11. Malmendier U., Tate G., Yan J. Overconfidence and early-life experiences: The effect of managerial traits on corporate financial policies. The Journal of Finance. 2011;66(5):1687-1733. DOI: 10.1111/j.15406261.2011.01685.x

12. Duxbury D. Behavioral finance: insights from experiments II: Biases, moods and emotions. Review of Behavioral Finance. 2015;7(2):151-175. DOI: 10.1108/RBF-09-2015-0037

13. Banerjee S., Humphery-Jenner M., Nanda V. Does CEO bias escalate repurchase activity? Journal of Banking \& Finance. 2018;93:105-126. DOI: 10.1016/j. jbankfin.2018.02.003

14. Zhang D. CEO dividend protection. Journal of Empirical Finance. 2018;45:194-211. DOI: 10.1016/j. jempfin.2017.10.005

15. Jiraporn P., Kim J.-C., Kim Y.S. Dividend payouts and corporate governance quality: An empirical investigation. The Financial Review. 2011;46(2):251279. DOI: 10.1111/j.1540-6288.2011.00299.x

16. Ambardnishvili T., Berezinets I., Ilina Y., Smirnov M. Board of directors and dividend policy in Russian companies with direct state ownership. Korporativnye finansy = Journal of Corporate Finance Research. 2017;11(1):50-77. DOI: 10.17323/j.jcfr.20730438.11.1.2017.50-77 (In Russ.). 
17. Stepanova A., Kuzmin S. Corporate governance and operational efficiency: Evidence from Russia. Korporativnye finansy $=$ Journal of Corporate Finance Research. 2011;5(4):24-39. DOI: 10.17323/j.jcfr.20730438.5.4.2011.24-39 (In Russ.).

18. Sharma V. Independent directors and the propensity to pay dividends. Journal of Corporate Finance. 2011;17(4):1001-1015. DOI: 10.1016/j. jcorpfin.2011.05.003

19. Chen J., Leung W.S., Song W., Goergen M. Why female board representation matters: The role of female directors in reducing male CEO overconfidence. Journal of Empirical Finance. 2019;53:70-90. DOI: 10.1016/j.jempfin.2019.06.002

20. Stepanova A., Tereshchenko A. The influence of independent directors, insider ownership and scientific connections on risky R\&D investments: Evidence from emerging markets. Korporativnye finansy = Journal of Corporate Finance Research. 2016;10(3):5-23. DOI: 10.17323/j.jcfr.20730438.10.3.2016.5-23

21. Anilov A., Ivashkovskaya I. Do boards of directors affect CEO behavior? Evidence from payout decisions. Higher School of Economics. Basic Research Program. Working Paper. 2018;(69). URL: https://wp.hse.ru/data/2018/11/08/1142520992/69 FE2018.pdf
22. Green C., Homroy S. Female directors, board committees and firm performance. European Economic Review. 2018;102:19-38. DOI: 10.1016/j. euroecorev.2017.12.003

23. Zagorchev A., Gao L. Corporate governance and performance of financial institutions. Journal of Economics and Business. 2015;82:17-41. DOI: 10.1016/j.jeconbus.2015.04.004

24. Yarram S.R., Dollery B. Corporate governance and financial policies: Influence of board characteristics on the dividend policy of Australian firms. Managerial Finance. 2015;41(3):267-285. DOI: 10.1108/MF-03-2014-0086

25. Black B., de Carvalho A.G., Gorga É. What matters and for which firms for corporate governance in emerging markets? Evidence from Brazil (and other BRIK countries). Journal of Corporate Finance. 2012;18(4):934-952. DOI: 10.1016/j. jcorpfin.2011.10.001

26. Mande V., Park Y., Son M. Equity or debt financing: Does good corporate governance matter? Corporate Governance: An International Review. 2012;20(2):195211. DOI: $10.1111 / \mathrm{j} .1467-8683.2011 .00897 . x$

27. Wooldridge J.M. Simple solutions to the initial conditions problem in dynamic, nonlinear panel data models with unobserved heterogeneity. Journal of Applied Econometrics. 2005;20(1):39-54. DOI: 10.1002/jae.770 